\title{
SHIFTING CULTIVATION PRACTICES IN BARAK VALLEY, INDIA - POLICY SCENARIOS FROM A SPATIALLY EXPLICIT LAND USE MODEL
}

\author{
Jyoti Misra $^{1 *}$, K.S. Rajan ${ }^{1}$ \\ ${ }^{1}$ International Institute of Information Technology, Gachibowli, Hyderabad, India - jyotimisra.misra@research.iiit.ac.in, \\ rajan@iiit.ac.in
}

KEY WORDS: Agent based modelling, Barak Valley, Land use change, Shifting cultivation

\begin{abstract}
:
Barak valley is a region in north east part of India where the practice of shifting cultivation is quite prevalent. Population growth coupled with the geographic isolation of the area have led to an increased pressure on land and a consequent decline in forest cover. The decrease of forests observed is spatially distributed and dependent on neighborhood rules. Hence, we look towards modelling the land use change to understand the land use changes and the factors affecting them. In this paper, we modify an agent-based land use model for modelling shifting cultivation to determine how various policy changes at a larger scale might affect the shifting cultivation practice in the region at the micro level. We explore scenarios like drastic population increase and availability of irrigation infrastructure in the area. Through the scenario analysis we explore how policies play a role in agriculture patterns and influence land use patterns.
\end{abstract}

\section{INTRODUCTION}

Shifting cultivation is a practice of agriculture quite prevalent in South-East Asia. Shifting cultivation involves clearing parcels of land under forest cover and using it for crop cultivation. Once the crop is harvested, the area is burnt and left to regenerate for a period of time known as fallow period. Various studies have shown the importance of a sufficiently long fallow period in maintaining the productivity of the land [4]. With increasing shifting cultivation in some regions, there is an increased pressure on land resources leading to a shortening of the fallow period. This not only decreases the productivity of the land but also necessitates the need for even greater land under cultivation to meet the same demands.

Land use change modelling is a technique that has been used to develop and evaluate future scenarios of land cover. Models that predict changes in shifting cultivation have been developed that capture quite accurately the processes behind shifting cultivation. Land use modelling has been done prominently from a change analysis perspective. Many land use change models are statistical with the future states of land use being achieved through extrapolation without taking the human factors, like decision making capabilities of the inhabitants, into consideration. A modelling effort has been done for Laos region where decision making was done at village level (Wada, Rajan, 2007). For this model, all the villages were rural areas with similar characteristics. The model considered the villages as the primary consumption units.

For the districts of Barak being considered in the paper, there exists a great variability in topography as well as land use patterns. Some areas of the region are urban with a much higher population density whereas there exist heavily forested regions as well. With the variations present in the population as well as yield patterns of the two study districts, we are looking to modify the model to accommodate the unique characteristics of the area. The current modelling approach is based on (Wada, Rajan , 2007). but since the spatial reference unit of district is used here instead of a village, the model has been suitable re-adapted to it. The model parameters have been modified keeping in mind the variability in landscape, land use practices of the regions as well as the population distribution.

The paper tries to assess the impact of different policy options available on the land use pattern, its choices and its interaction with the local population and its needs. In this paper, four scenarios have been modelled for a period of 30 years, from 2005-2035, to understand and evaluate how different policies affect the land use pattern at the micro level. The model is operated at a grid resolution of $500 \mathrm{~m}$.

In this paper, we'll discuss the area of study in the next section. In the third section we'll present details about the model being used. The fourth section discusses the scenarios used to simulate the different policies and the results of the model in each of these scenarios. Finally, in the fifth section, we report the results in detail and analyze how policies are affecting land use in the region.

\section{STUDY AREA}

Barak valley is a region in the north east part of India that lies between longitude of $92^{\circ} 15^{\prime}$ and $93^{\circ} 15^{\prime}$ East and latitude of $24^{\circ} 8^{\prime}$ and $25^{\circ} 8^{\prime}$ 'North and geographically isolated not only from mainstream of India but also from the rest of the state of Assam owing to difficult topography of the adjoining areas. It contains various districts over the two states of Assam and Mizoram.

The practice of shifting cultivation is quite prevalent in the Barak valley region. As shown in table 1, with the rise in economic 
growth the practice of shifting cultivation has dropped by $97 \%$ in the state of Assam and by only $30 \%$ in the state of Mizoram.

\begin{tabular}{|l|l|l|l|l|}
\hline State & $\begin{array}{l}\text { Shifting } \\
\text { Cultivation } \\
\text { Area (2000) }\end{array}$ & $\begin{array}{l}\text { Shifting } \\
\text { Cultivation } \\
\text { Area (2010) }\end{array}$ & $\begin{array}{l}\text { Change } \\
\left(\mathrm{km}^{2}\right)\end{array}$ & $\begin{array}{l}\% \\
\text { Decadal } \\
\text { change }\end{array}$ \\
\hline Assam & $8,391.48$ & 239.56 & -8151.9 & -97.15 \\
\hline Mizoram & $3,761.23$ & $2,617.56$ & -1143.6 & -30.41 \\
\hline
\end{tabular}

Year Book-2014 by MoSPI

Table 1. Area $\left(\mathrm{km}^{2}\right)$ under shifting cultivation for Assam and Mizoram

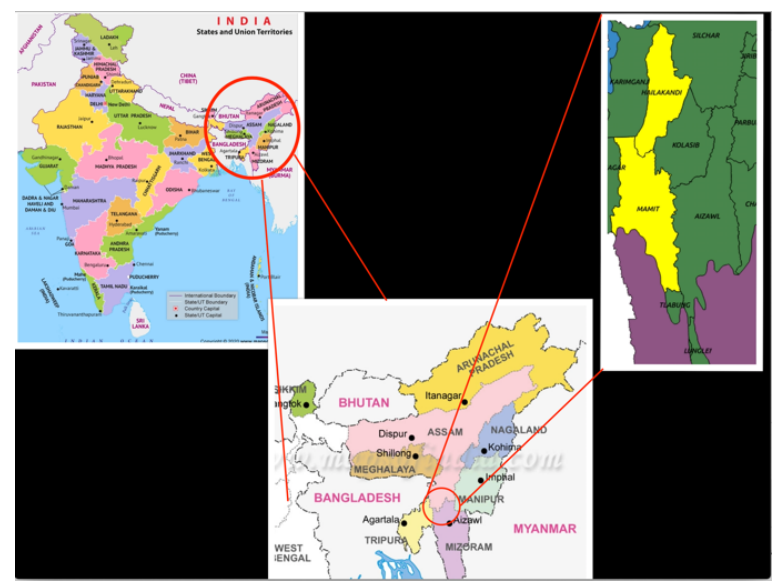

Figure 1. Location of the districts of Hailakandi and Mamit

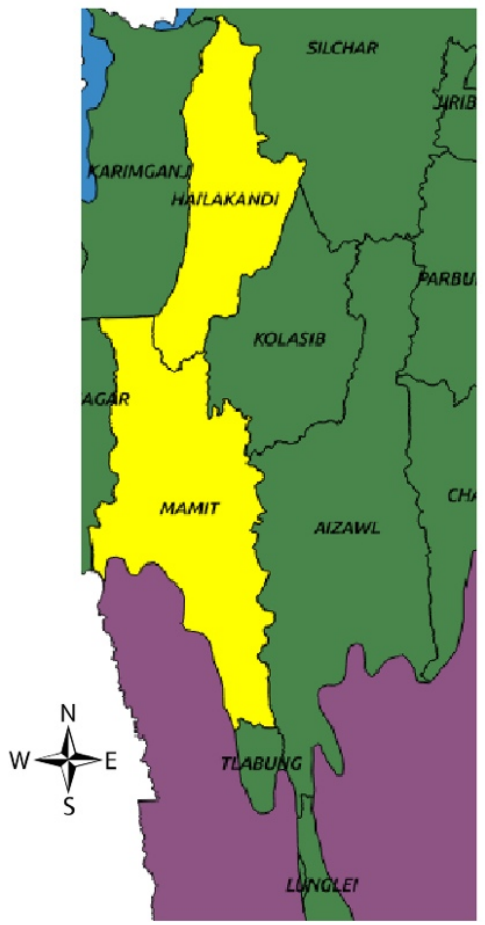

Figure 2. An enlarged view of the districts under consideration (highlighted yellow)
In our analysis we are considering districts lying in the southern region of Barak valley where shifting cultivation practices are more common. We are considering the two districts of Hailakandi and Mamit for our analysis which have an area of 1,327 sq. km. and $3025 \mathrm{sq}$. km. respectively.

All model output maps presented in the paper use UTM with WGS84 geographic coordinate system. Each pixel of the image denotes a $500 \mathrm{~m} \times 500 \mathrm{~m}$ land parcel. Each map is $100 \times 470$ pixels.

\section{MODEL DESCRIPTION}

The model framework in the paper examines shifting cultivation as a means of supply to meet the food demands of the region. It assumes that the food demands of the region must be met locally. Sources to meet the food demand may come through either shifting cultivation or settled means of agriculture, i.e., irrigated and seasonal cultivation. Hence the model is a demand driven model rather than an empirical or statistical change driven model. Here we are treating paddy as a proxy crop for major staple crop consumed in the region owing to its highest cropping acreage. The model is run at a grid scale of $500 \mathrm{~m}$.

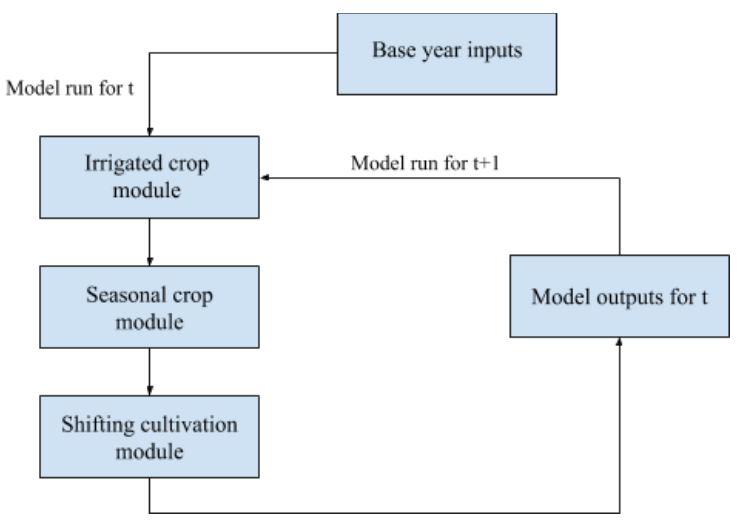

Figure 3. Model architecture

The districts act as agents in the model. The rice produced through settled means of agriculture is distributed among the various agents. The agents communicate their food demands with each other. Based on the demand supply gaps the amount of shifting cultivation needed is calculated by each individual district. The spatial distribution of the various types of agriculture depends on the environmental factors like slope of the area and proximity to river.

The model takes both spatial and tabular datasets as input. The model needs district boundary spatial data which provides us with the political boundary of each of the districts which are treated as individual agents in the model. Elevation and slope data are used for assigning different agricultural categories to cultivable land. Population data is needed to calculate food demand for each year. Coupled with population growth rate, it provides a means to track the increase in demand for the area. Population spatial data map is needed for district wise population and hence district demand. Land use data at a resolution of $500 \mathrm{~m}$ is used to provide the land use map for the base year.

Crop yield is used as a tabular input as the data provides us with year-wise yield of each of the four varieties of crops grown in the region. Population growth data provides the population increase happening every year and is needed to calculate the increased food demands. 
The model takes into account an existing land use map of the region and predicts the land use distribution of the region over a certain period of years (Misra, Rajan, 2018). The model starts with the knowledge about population, food demands, crop yields and existing land use map of the area. As shown in Figure 3, the model consists of three modules each representing a type of agriculture in the region, namely: irrigated cultivation module, seasonal cultivation module and shifting cultivation module.

The irrigated module deals with a settled form of agriculture that relies on man-made forms of irrigation infrastructure. The yields of irrigated cultivation are usually higher, owing to the avoidance of uncertainty that accompanies a reliance on weather conditions for irrigation of crops. The model assumes that with a growth in infrastructure over time, areas that are under seasonal cultivation would convert to irrigated cultivation thus increasing agricultural productivity. To account for this increase, it takes into consideration the proximity to water resources while keeping the growth in check owing to a limited rate of year-on-year infrastructure growth.

The seasonal cultivation module deals with the other form of agriculture that relies on seasonal rainfall as a means of irrigation. The expansion of seasonal cultivation is dependent on geographic features such as the slope of the region as well as neighbourhood rules. The shifting cultivation module takes into account the fallow period needed and reassigns parcels of land under forest cover for cropping under shifting cultivation based on the unfulfilled food demand that is still left over.

\begin{tabular}{|l|l|l|l|}
\hline & $\begin{array}{l}\text { Predicted } \\
\text { Irrigated } \\
\text { cultivation }\end{array}$ & $\begin{array}{l}\text { Predicted } \\
\text { Seasonal } \\
\text { Cultivation }\end{array}$ & $\begin{array}{l}\text { Predicted } \\
\text { Shifting } \\
\text { Cultivation }\end{array}$ \\
\hline $\begin{array}{l}\text { Actual } \\
\text { Irrigated } \\
\text { cultivation }\end{array}$ & 510 & 2 & 3 \\
\hline $\begin{array}{l}\text { Actual } \\
\text { Seasonal } \\
\text { Cultivation }\end{array}$ & 21 & 1478 & 96 \\
\hline $\begin{array}{l}\text { Actual } \\
\text { Shifting } \\
\text { Cultivation }\end{array}$ & 0 & 7 & 40 \\
\hline
\end{tabular}

Table 2. Confusion matrix for 1988-2005 model run_and validation based on 2005 land use map.

The model was calibrated for the period of 1988-1998 and validated for 2005 with an overall accuracy of about $94 \%$ as shown through the confusion matrix score in Table 2. These finetuned model parameters are used for the rest of this study to understand the impact of various policy scenarios on the land use outcomes in the region.

\section{SCENARIO BUILDING}

We want to understand the impact of policy, its interactions and effects on the landscape. For this we have come up with four different scenarios, including the business as usual (BAU) scenario, each representing a specific form of social or policy change. Each of these scenarios described below are simulated for the period of 2005 to 2035. The agent based model is used to explore the effect of social and economic factors on land use and agriculture patterns. All these scenarios are run independently.
Since the districts vary widely in their land use patterns, the scenarios are analysed in a district-wise pattern.

\begin{tabular}{|l|l|l|l|}
\hline & $\begin{array}{l}\text { Irrigated } \\
\text { Cultivation }\end{array}$ & $\begin{array}{l}\text { Seasonal } \\
\text { Cultivation }\end{array}$ & $\begin{array}{l}\text { Shifting } \\
\text { Cultivation }\end{array}$ \\
\hline Hailakandi & 508 & 1631 & 62 \\
\hline Mamit & 26 & 188 & 345 \\
\hline
\end{tabular}

Table 3. Number of land parcels of 25 ha each under various forms of land use for the year 2005

\subsection{Development of scenarios}

\subsubsection{Business as usual}

With the business as usual scenario, the model is allowed to run as-is. The parameter values are kept same as in the initial model run from 1988-2005. The parameter values are those that most accurately predicted the land use map for 2005. Through this scenario we want to look at the changes in land use of the region when no drastic policy changes are made for the area.

\subsubsection{Incentivisation settled agriculture}

The second scenario created was one in which settled forms of agriculture are incentivized through policy changes coupled with high infrastructure investments in the area. In this case we remove the capping parameters on the growth of irrigated and seasonal cultivation practices. This scenario expects a huge shift from shifting cultivation to settled cultivation forms.

\subsubsection{No growth of settled agriculture}

The first scenario created was one in which there was no increase in lands under irrigation. This corresponds to a policy change that deprioritizes infrastructure growth in the area. Lack of infrastructure growth in the area would limit the growth of irrigated cultivation since people would have to rely on the river for irrigation and hence would not be able to expand irrigated agriculture practices. The agriculture patterns are expected to move from high yielding irrigated cultivation towards low yielding seasonal and shifting cultivation.

\subsubsection{Doubling of population}

A third scenario was simulated that considers the social factors involved. We want to simulate what the land condition would be if there is a massive migration from nearby places to Barak valley in addition to the natural population growth of the region. Hence, we double the population of each of the districts. This scenario is expected to put a massive strain on land resources to meet the food demand of the increased population.

As shown in Figure 4, we consider an environment vs economic development quadrant method to explain the four scenarios that are modelled. The positive $\mathrm{x}$-axis corresponds to increased efforts for ecological conservation and the negative $\mathrm{x}$-axis denotes no efforts being made for ecological conservation. Similarly, the y-axis denotes economic growth of the region. If we plot each of the scenarios on the quadrant, we come up with a figure as shown in Figure 4. The BAU scenario, lies in the third quadrant as in BAU scenario, we are not taking any special efforts towards ecological conservation. Also since minimal 
efforts are being put into the growth of irrigation infrastructure, the economic growth does not seem to be great.

By contrast, for the scenario of incentivization of settled agriculture placed in the first quadrant, there are great investments being made into building irrigation infrastructure. This points to economic growth. As a result of increased irrigated cultivation, the amount of shifting cultivation is expected to reduce which helps in ecological conservation.

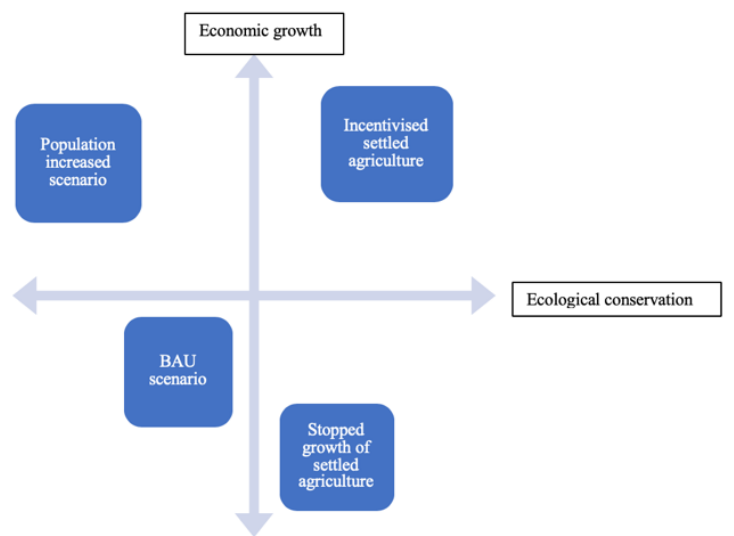

Figure 4. Economic growth vs ecological conservation quadrant

The scenario where population is increased is placed in the second quadrant and can be seen as an economic growth which has raised the food consumption and demands. The increased demands however, put a huge stress on the environment and leads to exploitation of land.

The scenario where growth of settled agriculture is stopped, is placed in the fourth quadrant. Stopped growth of settled agriculture can be seen as restrain on investments in infrastructure, which points towards a decrease in economic development. The decreased infrastructure growth, slowly but surely pushes towards high areas of lands under shifting cultivation which leads to degradation of forest cover.

\section{RESULTS OF SCENARIOS}

The two districts under consideration have very different land use patterns. The district of Hailakandi has a mix of urban and rural populations. With the presence of urban areas, the district also has a much higher population than the neighbouring district Mamit. Hailakandi has around $40 \%$ of its area under settled cultivation of which irrigated cultivation occupies $25 \%$. Shifting cultivation is minimal but present in around $2 \%$ of the total district area.

The district of Mamit has more of a rural population. It is sparsely populated and is a heavily forested district. Around $92 \%$ of the total land area in the district is forested. Shifting cultivation is practiced in the area and occupies around $6 \%$ of the total district area. The settled forms of agriculture are not as prominent taking up less than $2 \%$ of the land area. The district has low population and consequently low food demands as is evident by the low percentage of agricultural land in the district.

\subsection{Business As Usual Scenario}

The district of Hailakandi has a higher percentage of land under irrigated cultivation. It also has a higher population density. The population of Hailakandi is more than 5 times the population of Mamit for any given year. Consequently the demand of the district is much higher than that of Mamit district.

Hailakandi has a good mix of irrigated, seasonal and shifting cultivation with more practice of settled agriculture. The district of Mamit however has more reliance on shifting cultivation. The amount of area under irrigated cultivation is very low in the district due to a lack of infrastructure resources.

Mamit however has both seasonal as well as shifting cultivation that cater to the food demands of the district.

\begin{tabular}{|l|l|l|l|}
\hline $\begin{array}{l}\text { Business- } \\
\text { As-Usual } \\
\text { Scenario }\end{array}$ & $\begin{array}{l}\text { Irrigated } \\
\text { Cultivation }\end{array}$ & $\begin{array}{l}\text { Seasonal } \\
\text { Cultivation }\end{array}$ & $\begin{array}{l}\text { Shifting } \\
\text { Cultivation }\end{array}$ \\
\hline Hailakandi & 572 & 1768 & 598 \\
\hline Mamit & 82 & 1488 & 3971 \\
\hline
\end{tabular}

Table 4. Number of land parcels of 25 ha each under various forms of land use in the business as usual scenario for the year 2035

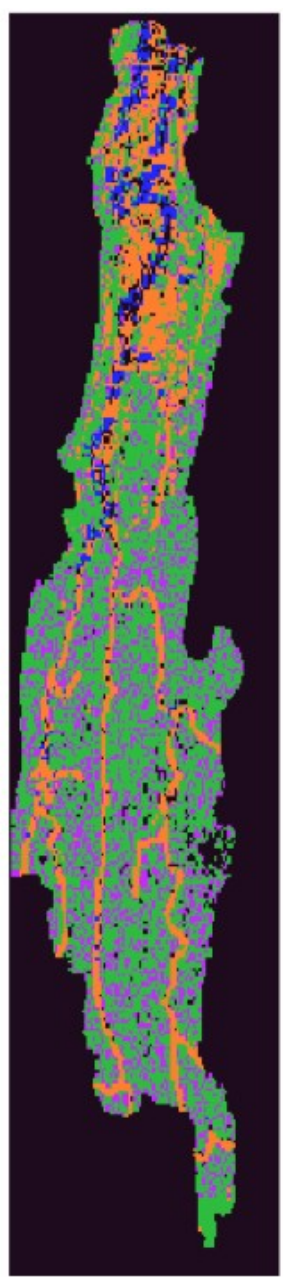

Forest

Irrigated Cultivation

Seasonal Cultivation

Shifting Cultivation

Other Crops

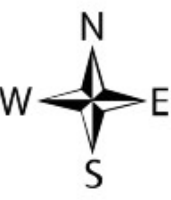

Figure 5. Land use map for 2035 when simulated with business as usual scenario for the year 2035 


\subsection{Incentivisation of settled forms of agriculture}

When settled forms of agriculture are allowed to grow with no restrictions, we can see a shift towards the high yielding irrigated cultivation. The irrigated form of cultivation has much higher yields irrespective of the district.

Compared to the BAU scenario, we can see a huge increase in the area under irrigated cultivation for both the districts. The amount of area under seasonal cultivation and shifting cultivation falls. This is due to the high yield of irrigated cultivation which can satisfy the food demands of the region more easily. Both the districts show a remarked reduction in the area under shifting cultivation.
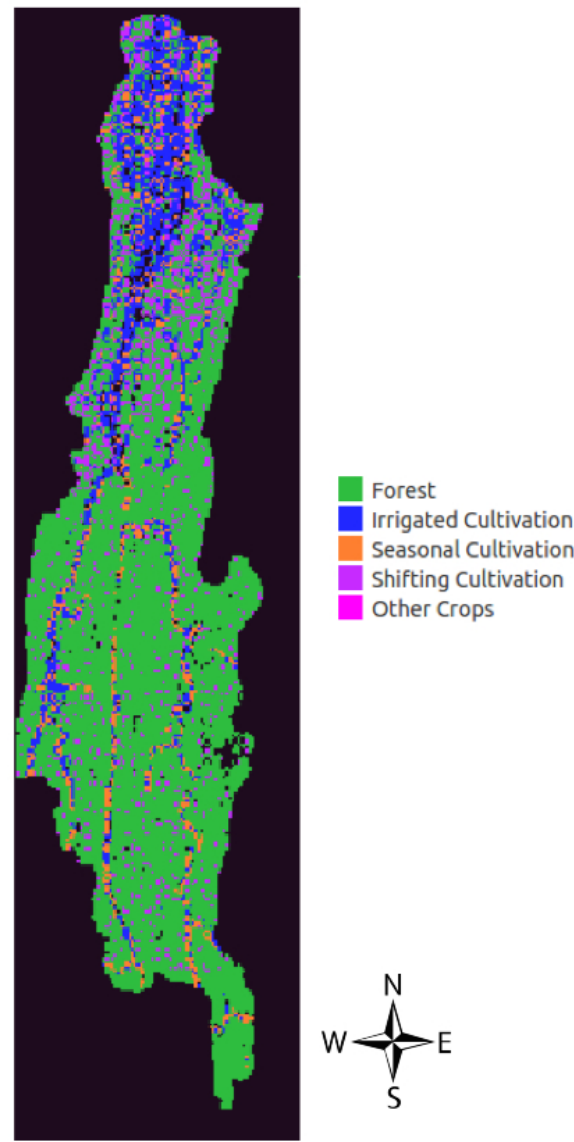

Figure 6. Land use map for 2035 when simulated with Incentivisation of settled forms of agriculture scenario for the year 2035

\begin{tabular}{|l|l|l|l|}
\hline $\begin{array}{l}\text { Incentivized } \\
\text { Settled } \\
\text { Agriculture } \\
\text { Scenario }\end{array}$ & $\begin{array}{l}\text { Irrigated } \\
\text { Cultivation }\end{array}$ & $\begin{array}{l}\text { Seasonal } \\
\text { Cultivation }\end{array}$ & $\begin{array}{l}\text { Shifting } \\
\text { Cultivation }\end{array}$ \\
\hline Hailakandi & 925 & 1120 & 832 \\
\hline Mamit & 390 & 87 & 23 \\
\hline
\end{tabular}

Table 5. Number of land parcels of 25 ha each under various forms of land use in the incentivized settled agriculture scenario for the year 2035

\subsection{No growth of irrigated cultivation form}

When increase of irrigated cultivation is stopped completely, there occurs a shift towards other forms of agriculture to meet the food demand. In the district of Hailakandi, there occurs a shift towards shifting agriculture. The shifting cultivation of the district increases to meet the food demand of the district.

For the district of Mamit, there occurs an increase in the land under seasonal cultivation. For Mamit, the yields of seasonal and irrigated cultivation are almost the same. Hence the shift in seasonal cultivation is enough to meet the food demands of the district.

\begin{tabular}{|l|l|l|l|}
\hline $\begin{array}{l}\text { Stopped } \\
\text { Irrigated } \\
\begin{array}{l}\text { Cultivation } \\
\text { Increase } \\
\text { Scenario }\end{array}\end{array}$ & $\begin{array}{l}\text { Irrigated } \\
\text { Cultivation }\end{array}$ & $\begin{array}{l}\text { Seasonal } \\
\text { Cultivation }\end{array}$ & $\begin{array}{l}\text { Shifting } \\
\text { Cultivation }\end{array}$ \\
\hline Hailakandi & 508 & 1833 & 623 \\
\hline Mamit & 26 & 1546 & 3980 \\
\hline
\end{tabular}

Table 6. Number of land parcels of 25 ha each under various forms of land use in the stopped irrigated cultivation increase scenario for the year 2035

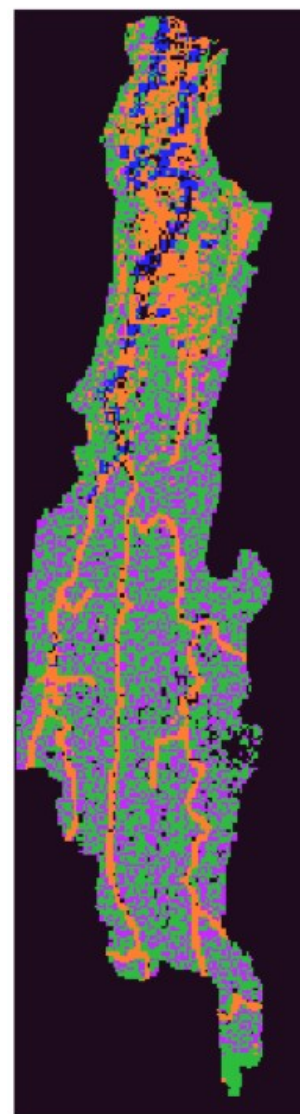

Forest

Irrigated Cultivation

Seasonal Cultivation

Shifting Cultivation

Other Crops<smiles>[Y]C1NC(C)CS1</smiles>

Figure 7. Land use map for 2035 when simulated with stopped growth of irrigated cultivation scenario for the year 2035 


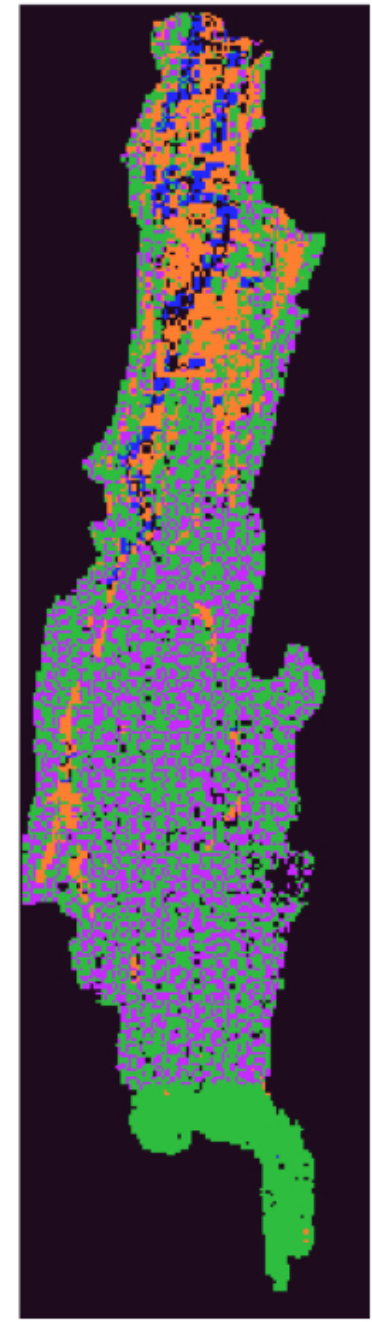

\section{Forest \\ Irrigated Cultivation Seasonal Cultivation Shifting Cultivation Other Crops}<smiles>[Y]C1NC(F)C(F)S1</smiles>

Figure 8. Land use map for 2035 when simulated with stopped growth of all settled agriculture scenario for the year 2035

\begin{tabular}{|l|l|l|l|}
\hline $\begin{array}{l}\text { Stopped } \\
\text { Irrigated } \\
\text { Cultivation } \\
\text { Increase and } \\
\begin{array}{l}\text { Stopped } \\
\text { Seasonal } \\
\text { Cultivation } \\
\text { Increase }\end{array}\end{array}$ & $\begin{array}{l}\text { Irrigated } \\
\text { Cultivation }\end{array}$ & $\begin{array}{l}\text { Seasonal } \\
\text { Cultivation }\end{array}$ & $\begin{array}{l}\text { Shifting } \\
\text { Cultivation }\end{array}$ \\
\hline Hailakandi & 508 & 1631 & 923 \\
\hline Mamit & 26 & 188 & 6267 \\
\hline
\end{tabular}

Table 7. Number of land parcels of 25 ha each under various forms of land use in the stopped irrigated cultivation increase and stopped seasonal cultivation increase scenario for the year 2035

Since the irrigated cultivation growth rate is very slow, we do not see much effect on agriculture patterns once its stopped. So, another scenario is run where growth of all forms of settled agriculture is stopped.
For the district of Hailakandi, shifting cultivation increases rapidly from the Business as usual scenario. With the increase of irrigated and seasonal forms of agriculture stopped, shifting cultivation rises to meet the increasing food demands. The district of Hailakandi has a large variation between the yields of settled forms of agriculture and the yield of shifting agriculture. Consequently, more shifting cultivation area is needed to meet the same food demand.

For the district of Mamit, the crop yields of settled and shifting cultivation are almost similar. With a lower food demand due to a lower population, the increase in shifting cultivation is not as drastic as for the district of Hailakandi.

\subsection{Doubling of population}

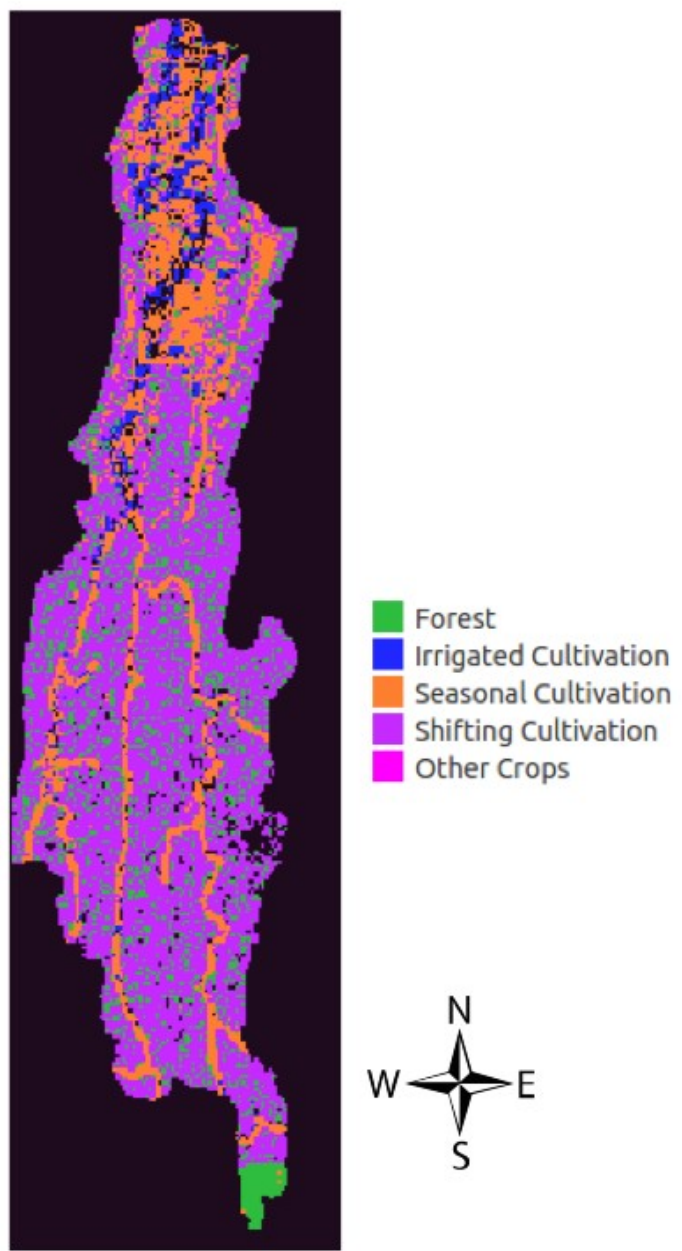

Figure 9. Land use map for 2035 when simulated with doubled population scenario for the year 2035

The scenario where population is doubled puts a lot of stress on the land resources of the region. Due to the presence of better infrastructural resources, Hailakandi is able to handle the spike in population a little better than the district of Mamit. The irrigated cultivation increases to meet the increased demand, but due to infrastructure limits, isn't able to rise sufficiently enough to meet the increased food demand. There occurs an increase in seasonal cultivation to support the increased demand of the population. However, this increase in seasonal cultivation as well is not enough to satisfy the food demand. We see a sharp increase in shifting cultivation for Hailakandi district. 
Mamit has a lower population than Hailakandi. We see an increase in settled agriculture but owing to lower infrastructure resources, these are not enough for the doubled population. Consequent a drastic increase in shifting cultivation is seen which increases to approximately three times the BAU value to account for the increased food demands of the district

\begin{tabular}{|l|l|l|l|}
\hline $\begin{array}{l}\text { Doubled } \\
\text { Population } \\
\text { Scenario }\end{array}$ & $\begin{array}{l}\text { Irrigated } \\
\text { Cultivation }\end{array}$ & $\begin{array}{l}\text { Seasonal } \\
\text { Cultivation }\end{array}$ & $\begin{array}{l}\text { Shifting } \\
\text { Cultivation }\end{array}$ \\
\hline Hailakandi & 569 & 1775 & 2618 \\
\hline Mamit & 85 & 1497 & 10000 \\
\hline
\end{tabular}

Table 8. Number of land parcels of 25 ha each under various forms of land use in the doubled population scenario for the year 2035

\section{DISCUSSION OF RESULTS}

In Figure 10, we can see the changes in shifting cultivation over the various scenarios for the two districts. Hailakandi is a mix of urban and rural areas and has a lower shifting cultivation area than its neighbouring district of Mamit which is primarily a rural district.

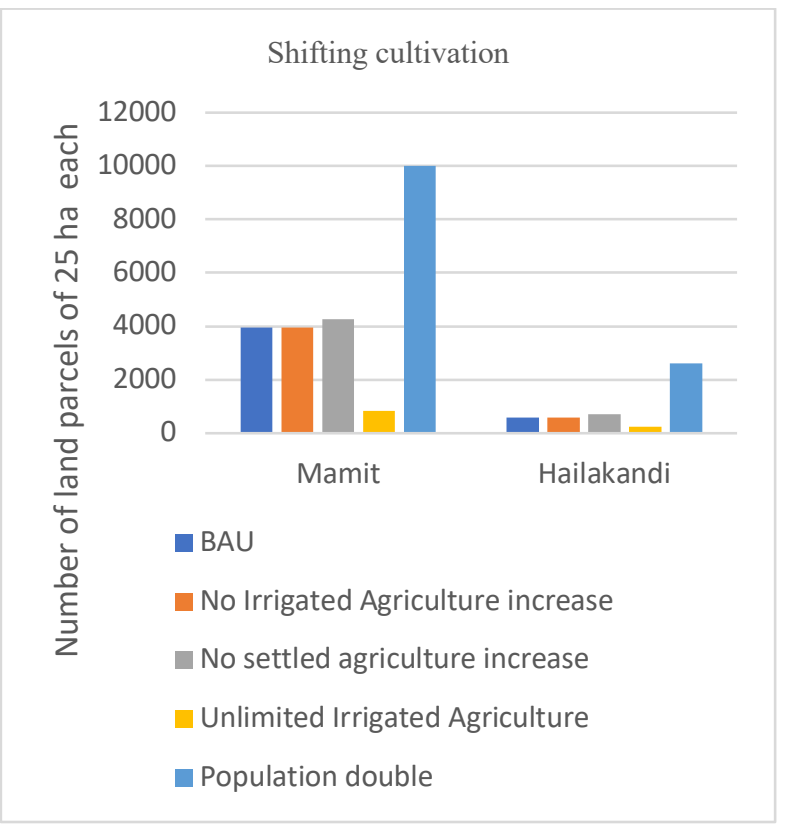

Figure 10. Changes in shifting cultivation over different scenarios

For the district of Hailakandi, the amount of area under shifting cultivation does not change much when the increase of irrigated cultivation is stopped. When all forms of settled agriculture are stopped, we do see a slight increase in the shifting cultivation area. This is to compensate for the gap in demand-supply created when settled forms of agriculture are restricted. However, when settled forms of agriculture are allowed to expand unbounded, we see an immediate drop in shifting cultivation. This is so because the high yielding settled form of cultivation can meet the food demand of the region through lower utilization of land resources.
When population of the district is doubled, we see a sudden increase in shifting cultivation. The settled forms of agriculture in this scenario are unable to meet the food demands of the district and consequently fall back on shifting cultivation to meet the demand-supply gap.

As seen in Figure 10, the district of Mamit has a much greater area under shifting cultivation. Shifting cultivation in Mamit too follows a pattern similar to the shifting cultivation in Hailakandi district. The area under shifting cultivation in stopped irrigated agriculture scenario, remains almost same as the BAU scenario. This can be explained by the absence of irrigated cultivation in Mamit district. Since the district of Mamit has very less area under irrigated cultivation, stopping the growth of irrigated cultivation does not affect the district greatly. When both forms of settled agriculture are restricted, we do see a slight increase in shifting cultivation as it grows to meet the food demand of the district. As in the district of Hailakandi, we see a huge increase in shifting cultivation when population is doubled. Owing to the lack of settled agriculture in the region, a huge strain is put on the land resources to meet the increased food demand. Contrastingly, when settled agriculture is allowed to grow unbounded, the increase in irrigated and seasonal cultivation is able to meet the food demands of the district more efficiently. Consequently, shifting cultivation of the district falls.

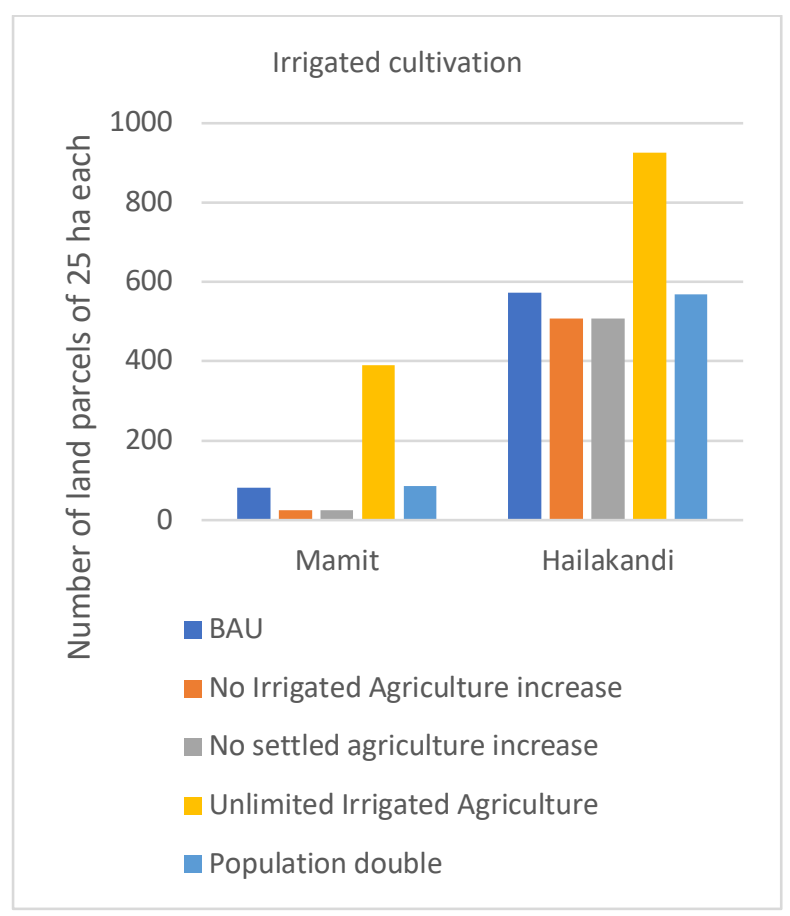

Figure 11. Changes in irrigated cultivation over different scenarios

However, when the population of the district is doubled, we see quite a jump in shifting cultivation area. The land area under shifting cultivation rises to meet the food demands of the increased population. Analysing these scenarios show that with proper infrastructural development shifting cultivation can be decreased and eventually discontinued in these district.

Now let's take a look at the changes in irrigated cultivation over the different scenarios simulated as shown in Figure 11. We can observe that area under irrigated cultivation is much higher for Hailakandi district. This is due to better infrastructure resources in the region. The district of Hailakandi is more urbanized and 
consequently has more population as well. Mamit on the other hand has higher percentage of its area under forests.

Over the scenario runs for Hailakandi, we can see that when a cap is put on the growth of irrigated cultivation, there is not much difference from BAU scenario. This is due to the low increase rate for irrigated cultivation which demonstrates the low rate of infrastructure growth. When population is doubled for the district, we can see an increase in irrigated cultivation. However, since the irrigated cultivation is limited by infrastructure growth, we do not see a drastic change. When the cap on increase of irrigated cultivation is removed and settled forms of agriculture are allowed to grow freely, we can see a huge jump in irrigated cultivation. This increase in the higher yielding irrigated cultivation meets the food demands of the district more efficiently and shifting cultivation is no longer needed.

For the district of Mamit, the area under irrigated cultivation is much lower. When irrigated cultivation is not allowed to increase, we can see a drop compared to the BAU scenario which shows minimal lands under irrigated cultivation. Even when population is doubled, there is not a huge change in the area of irrigated cultivation. This is due to the limited infrastructure resources in the region that limit the growth of irrigated cultivation. However, when the irrigated cultivation growth is incentivized, we see a huge increase in area under irrigated cultivation. This shows the potential of the district for adapting to more efficient form of agriculture which can be encouraged by investing in infrastructure growth of the region.

\section{CONCLUSIONS}

The agent-based model based on AGENT-LUC (Wada, Rajan, 2007) used here is able to show us how policies effect land use patterns. The different scenarios used for the generation of future land use demonstrate the importance of human factors in land use change. The scenarios also demonstrate how areas with different land topography and demographic respond differently to the same stimuli.
The model prediction is limited by data quality. The presence of better quality data can greatly improve the model performance. Similar statements can be made about the presence of social data in spatial formats which can enable a better understanding of the current situation and hence better predictions. The simulation scenarios presented can be expanded to include more complex cases that take into account the various socio-economic factors and how they affect the environment.

\section{REFERENCES}

Cairns, M., Garrity, D.P. Improving shifting cultivation in Southeast Asia by building on indigenous fallow management strategies. Agroforestry Systems 47, 37-48 (1999)

M. R. Jepsen, S. Leisz, K. Rasmussen, J. Jakobsen, L. MØllerJensen \& L. Christiansen (2006) Agent-based modelling of shifting cultivation field patterns, Vietnam, International Journal of Geographical Information Science, 20:9, 1067-1085, DOI: $10.1080 / 13658810600830848$

Maria Clara Silva-Forsberg, Philip M. Fearnside, Brazilian Amazonian caboclo agriculture: effect of fallow period on maize yield, Forest Ecology and Management, Volume 97, Issue 3,1997, Pages 283-291, ISSN 0378-1127, https://doi.org/10.1016/S0378-1127(97)00070-4.

Misra, J., Rajan, K. S (2018). Modelling Shifting Cultivation and Changes to Land Use in Barak Valley

Oliver T Coomesa, Franque Grimard, Graeme JBurt, Tropical forests and shifting cultivation: secondary forest fallow dynamics among traditional farmers of the Peruvian Amazon, Ecological Economics, Volume 32, Issue 1, January 2000, Pages 109-124

Wada, Y., Rajan, K. S., \& Shibasaki, R. (2007). Modelling the Spatial Distribution of Shifting Cultivation in Luangprabang, Lao PDR. Environment and Planning B: Planning and Design, 34(2), 261-278. https://doi.org/10.1068/b31180 